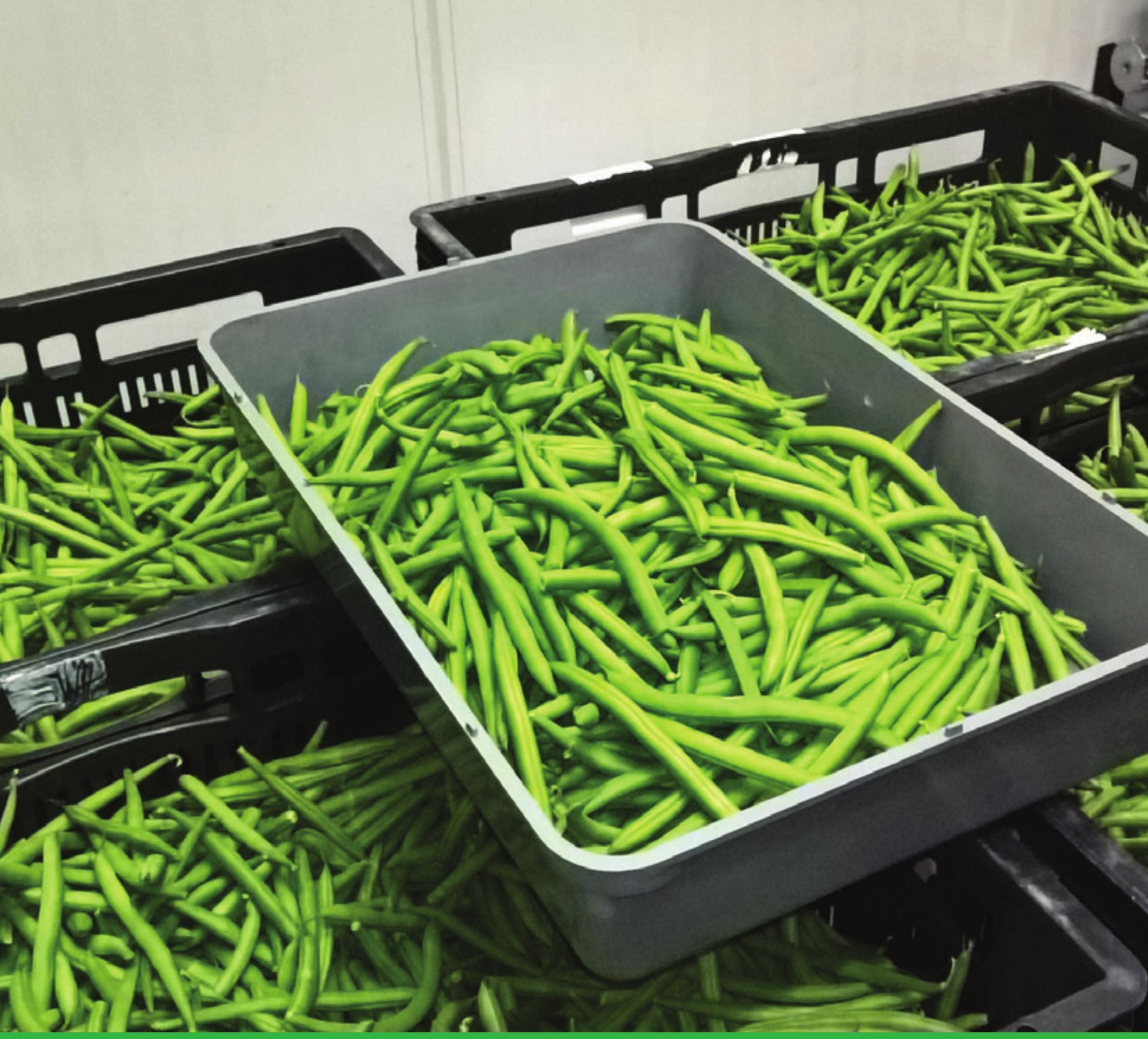

Het volgen van de kwaliteit van sperziebonen in de keten

GreenCHAINge WP1 - Sperziebonen

Bastiaan Brouwer, Harmannus Harkema, Hans de Wild en Suzan Gabriëls

WAGENINGEN

UNIVERSITY \& RESEARCH 



\title{
Het volgen van de kwaliteit van sperziebonen in de keten
}

\author{
GreenCHAINge WP1 - Sperziebonen
}

Auteurs: Bastiaan Brouwer, Harmannus Harkema, Hans de Wild en Suzan Gabriëls

Instituut: Wageningen Food \& Biobased Research

Dit onderzoek is uitgevoerd door Wageningen Food \& Biobased Research in opdracht van Bakker Barendrecht en Koninklijke Vezet BV en gefinancierd door Foundation TKI Horticulture, in het kader van GreenCHAINge (projectnummer 62390903-01).

Wageningen Food \& Biobased Research

Wageningen, november 2018

Rapport 1887 
Versie: definitief

Vertrouwelijk tot en met: december 2019

Reviewer: Manon Mensink

Goedgekeurd door: Nicole Koenderink

Opdrachtgever: Bakker Barendrecht en Koninklijke Vezet BV

Financier: Foundation TKI Horticulture

(C) 2018 Wageningen Food \& Biobased Research, instituut binnen de rechtspersoon Stichting Wageningen Research.

Vertrouwelijk rapport. Uit deze uitgave mag niets worden gereproduceerd en/of openbaar gemaakt zonder voorafgaande schriftelijke toestemming van de directeur van Wageningen Food \& Biobased Research.

Dit rapport is vanaf december 2019 gratis te downloaden op https://doi.org/10.18174/563039 of op www.wur.nl/wfbr (onder publicaties).

Postbus 17, 6700 AA Wageningen, T 03174800 84, E info.wfbr@wur.nl, www.wur.nl/wfbr. Wageningen Food \& Biobased Research is onderdeel van Wageningen University \& Research.

Alle rechten voorbehouden. Niets uit deze uitgave mag worden verveelvoudigd, opgeslagen in een geautomatiseerd gegevensbestand of openbaar gemaakt in enige vorm of op enige wijze, hetzij elektronisch, hetzij mechanisch, door fotokopieën, opnamen of enige andere manier, zonder voorafgaande schriftelijke toestemming van de uitgever. De uitgever aanvaardt geen aansprakelijkheid voor eventuele fouten of onvolkomenheden. 


\section{Inhoud}

$\begin{array}{ll}\text { Samenvatting } & 4\end{array}$

$\begin{array}{lc}\text { Summary } & 5\end{array}$

$1 \quad$ Inleiding $\quad 6$

$\begin{array}{ll}1.1 \text { Doel } & 6\end{array}$

$\begin{array}{ll}1.2 \text { Onderzoeksvraag } & 6\end{array}$

2 Methoden $\quad 7$

$\begin{array}{lll}2.1 & \text { Proefmateriaal en verzameling kwaliteitsdata } & 7\end{array}$

$\begin{array}{lll}2.2 & \text { Data analyse } & 7\end{array}$

$3 \quad$ Resultaten en discussie $\quad 8$

3.1 Transformatie kwaliteitsdata Bakker Barendrecht naar percentages $\quad 8$

$\begin{array}{llr}3.2 & \text { Vergelijking kwaliteit } & 8\end{array}$

$4 \quad$ Conclusies en aanbevelingen $r$

Bijlage 1 Beoordeling sperziebonen (Bakker Barsibiecht;

$\begin{array}{llr}\text { Bijlage } 2 & \text { Beoordeling sperziebonen (Vezet) } & 17\end{array}$ 


\section{Samenvatting}

Het algemene doel van GreenCHAINge werkpakket 1 is het ontwikkelen van een meer generiek kwaliteitscontrolesysteem voor de $\mathrm{AH}$ logistieke keten om een constantere kwaliteit te bereiken. Een van de deelprojecten is het onderzoek naar sperziebonen. Het doel van dit onderzoek is om beter inzicht te krijgen in het kwaliteitsverloop in de keten en zo mogelijk oorzaken aan te wijzen van kwaliteitsverlies.

Om meer inzicht te krijgen in het kwaliteitsverloop van sperziebonen in de keten van de distributeur Bakker Barendrecht naar de verwerker Koninklijke Vezet BV (hierna: Vezet), is een monitoringsexperiment uitgevoerd. Hierbij werden bij Vezet monsters genomen van een groot aantal partijen sperziebonen en vervolgens beoordeeld op verschillende soorten schade. Deze monsters zijn vervolgens gekoppeld aan de kwaliteitsdata van Bakker Barendrecht, waarna er bij Wageningen Food \& Biobased Research een onafhankelijke data-analyse is uitgevoerd.

De kwaliteitscontrole vond bij Bakker Barendrecht en Vezet op een verschillende manier plaats. Bij Bakker Barendrecht werd visueel gescoord in 5 klassen terwijl bij Vezet een gewichtspercentage van iedere afwijking werd bepaald. Om de data-analyse met deze twee datasets uit te kunnen voeren met dezelfde eenheden, zijn de scores van Bakker Barendrecht omgerekend naar percentages.

De belangrijkste resultaten uit dit onderzoek en de daaruit voortkomende adviezen zijn:

- Uit de data-analyse blijkt dat de resultaten van de kwaliteitsbeoordeling bij Bakker Barendrecht en Vezet niet logisch met elkaar samen hangen. Er zijn verschillende verklaringen mogelijk:

- $\quad$ Dit is mogelijk te verklaren met verschillen in kwaliteitscontrole. Verschillen in kwaliteitscontrole tussen Bakker Barendrecht en Vezet kunnen optreden door verschillen in monstername en/of meetmethode. Het advies is om de kwaliteitscontrole bij beide bedrijven te gaan afstemmen: op dezelfde monsters, door dezelfde personen, op dezelfde plaats en tijdstip.

- $\quad$ Een andere verklaring zou kunnen zijn dat de schade is toegenomen in de keten tussen de twee bedrijven. Echter, uit de huidige analyse lijkt de tijdsduur vanaf ontvangst bij Bakker Barendrecht tot aan beoordeling bij Vezet geen verband te houden met het niveau van de gemeten schade.

Dit document is het resultaat van onderzoek binnen GreenCHAINge werkpakket 1. Dit onderzoek is uitgevoerd tussen juni 2017 en januari 2018 door onderzoekers van Wageningen Food \& Biobased Research (WFBR). Dit is een objectief en onafhankelijk onderzoek, voor Bakker Barendrecht en Vezet, die gedeeltelijk aan dit onderzoek bijgedragen hebben middels in-kind en in-cash bijdrage. Dit document is vertrouwelijk en bedoeld voor Bakker Barendrecht, Vezet en WFBR. 


\section{Summary}

The general objective in GreenCHAINge workpackage 1 is to develop a more generic quality control system for the $\mathrm{AH}$ logistic chain, in order to achieve a more consistent quality.

One of the subprojects is the research on green beans. The aim of this research is to gain a better understanding of the quality of the chain and, if possible, to identify causes of quality loss.

To gain more insight into the quality of green beans in the chain from the distributor Bakker Barendrecht to the processing company Vezet, a monitoring experiment has been carried out. At Vezet samples were taken from a large number of batches of green beans and assessed for different types of damage. These samples were linked to the quality data of Bakker Barendrecht, based on independent data analysis performed by Wageningen Food \& Biobased Research.

The quality control took place at Bakker Barendrecht and Vezet. Bakker Barendrecht scored visually in five classes, while at Vezet an exact percentage of the weight of each damage was determined. In order to perform the data analysis of these two datasets with the same units, the scores of Bakker Barendrecht were converted to percentages.

The main results of this research and the resulting advices are as follows:

- The data analysis shows that the results of the quality assessment at Bakker Barendrecht and Vezet do not logically coincide. There can be several explanations:

- $\quad$ There may be differences in quality control between Bakker Barendrecht and Vezet. This can be a different sampling and/or measurement method. The advice is to align quality control between the two companies: on the same samples, by the same persons, at the same place and time.

- Another explanation could that the damage has increased in the chain between the two companies. However, the current analysis indicates that the length of time from Bakker Barendrecht until the assessment at Vezet is not related to the level of the damage measured.

This document is the result of a study as part of GreenCHAINge workpackage 1. This study is executed from June 2017 till January 2018 by researchers of Wageningen Food \& Biobased Research (WFBR), who performed an objective and independent study for Bakker Barendrecht and Vezet, who partly financed this project in-cash and in-kind.

This report is confidential and intended only for Bakker Barendrecht, Vezet and WFBR. 


\section{$1 \quad$ Inleiding}

Bij sperziebonen kan in de keten van productie tot verwerking op verschillende plaatsen ongewenste schade ontstaan. Deze schade kan verschillende vormen hebben, zoals beschadiging,

bruinverkleuring, windschade, afwijkende mat $(<8 \mathrm{~mm}$ of $>11 \mathrm{~mm})$, ziekte en slapheid. Sommige van deze schades kunnen vooral aan de teelt gekoppeld worden (windschade, afwijkende maat), andere juist aan teelt, oogst en verwerking (beschadiging) en naoogstcondities (bruinverkleuring, ziekte). In de praktijk komen verschillende soorten schades op verschillende momenten in het jaar voor. Ook bestaat het vermoeden dat de schade samenhangt met de herkomst van de bonen.

Om meer inzicht te krijgen in het kwaliteitsverloop van sperziebonen in de keten van de producenten, via de distributeur Bakker Barendrecht naar de verwerker Vezet, is een monitoringsexperiment ingezet. In dit monitoringsexperiment werden bij Vezet monsters genomen van verschillende partijen sperziebonen en vervolgens beoordeeld op verschillende soorten schade. Deze monsters zijn vervolgens gekoppeld aan de kwaliteitsdata van Bakker Barendrecht, waarna er bij Wageningen Food \& Biobased Research een onafhankelijke data-analyse is uitgevoerd.

Uit deze analyse komt het advies om de kwaliteitsbeoordeling tussen de bedrijven nader af te stemmen, om daarmee het inzicht in het kwaliteitsverloop in de keten te verbeteren.

Dit onderzoek is tot stand gekomen in samenwerking met Bakker Barendrecht en Koninklijke Vezet BV.

\subsection{Doel}

Het doel van dit onderzoek is inzicht te verkrijgen in het kwaliteitsverloop van sperziebonen door de keten, en mogelijke oorzaken aan te geven van kwaliteitsafname.

\subsection{Onderzoeksvraag}

Dit onderzoek beoogt antwoord te geven op de vraag: Is er een relatie tussen de data verkregen na de kwaliteitscontrole bij Bakker Barendrecht en de data verkregen na kwaliteitscontrole bij Vezet? 


\section{$2 \quad$ Methoden}

\subsection{Proefmateriaal en verzameling kwaliteitsdata}

Sperziebonen werden op gangbare wijze geteeld, geoogst en getransporteerd naar Bakker Barendrecht. Bij Bakker Barendrecht werden de bonen bij binnenkomst visueel gekeurd. De homogeniteit van de kleur van het monster werd hierbij bepaald aan een beperkt aantal monsters (schaal 1 tot 5 waarbij $1=$ niet uniform, $5=$ uniform).

Bij de overige uitgebreidere kwaliteitsbeoordelingen werd ook een schaal gebruikt van 1 tot 5 , maar gebaseerd op het percentage bonen met de volgende kenmerken (zie ook bijlage 1):

- $\quad$ Beschadiging

- $\quad$ Bruinverkleuring

- Windschade

- $\quad$ Sortering

- Ziekte/schimmel

Door Bakker Barendrecht zijn er van juni tot en met december 2017 in totaal 94 monsters beoordeeld. $\mathrm{Na}$ deze kwaliteitsbeoordeling werden de bonen opgeslagen en vervolgens getransporteerd naar Vezet.

Bij Vezet werden de bonen bij binnenkomst bemonsterd $(500 \mathrm{~g})$ en het monster tijdelijk opgeslagen in een plastic zak. De monsters werden vervolgens gekeurd op verschillende kenmerken.

Ook hier werd de homogeniteit van de kleur van het monster bepaald volgens schaal 1 tot 5 . De beoordeling van de overige kenmerken werd echter op een andere manier uitgevoerd dan bij Bakker Barendrecht. Per monster werden de hoeveelheden bonen per kenmerk gewogen en de gewichten genoteerd (zie bijlage 2). Behalve de hierboven opgesomde kenmerken werd ook 'slap' gescoord. Deze gewichten werden vervolgens omgerekend naar gewichtspercentages (\% van 500 gram monster). Door Vezet zijn er van juni tot en met december 2017 in totaal 158 monsters beoordeeld.

Ieder monster werd gekoppeld aan een GB-nummer, ordernummer en palletnummer. Deze nummers werden gebruikt om Bakker Barendrecht in staat te stellen hun kwaliteitsdata te kunnen koppelen aan de data van Vezet. De gecombineerde kwaliteitsdata werd vervolgens naar Wageningen Food \& Biobased Research gestuurd voor een data analyse.

\subsection{Data analyse}

Allereerst werden de kwaliteitsdata van Bakker Barendrecht omgerekend naar gewichtspercentage volgens de criteria van de beoordeling (Figuur 1). Vervolgens werden de monsters op de aangeleverde tijdsvolgorde uiteengezet en geanalyseerd. Data verwerking en analyse is uitgevoerd met Microsoft Excel, multivariaat analyse is uitgevoerd met Unscrambler X (Camo, Oslo, Norway). 


\subsection{Transformatie kwaliteitsdata Bakker Barendrecht naar percentages}

De kwaliteitscontrole vond bij Bakker Barendrecht en Vezet op een verschillende manier plaats. Bij Bakker Barendrecht werd visueel gescoord in vijf klassen terwijl bij Vezet een gewichtspercentage van iedere afwijking werd bepaald.

Om vergelijking van de kwaliteitsdate van beide bedrijven mogelijk te maken en data-analyse met deze twee datasets uit te kunnen voeren, zijn de scores van Bakker Barendrecht omgerekend naar een benaderd percentage (Figuur 1). Op deze manier kan bepaald worden hoe de kwaliteit verandert in de keten tussen de twee bedrijven.

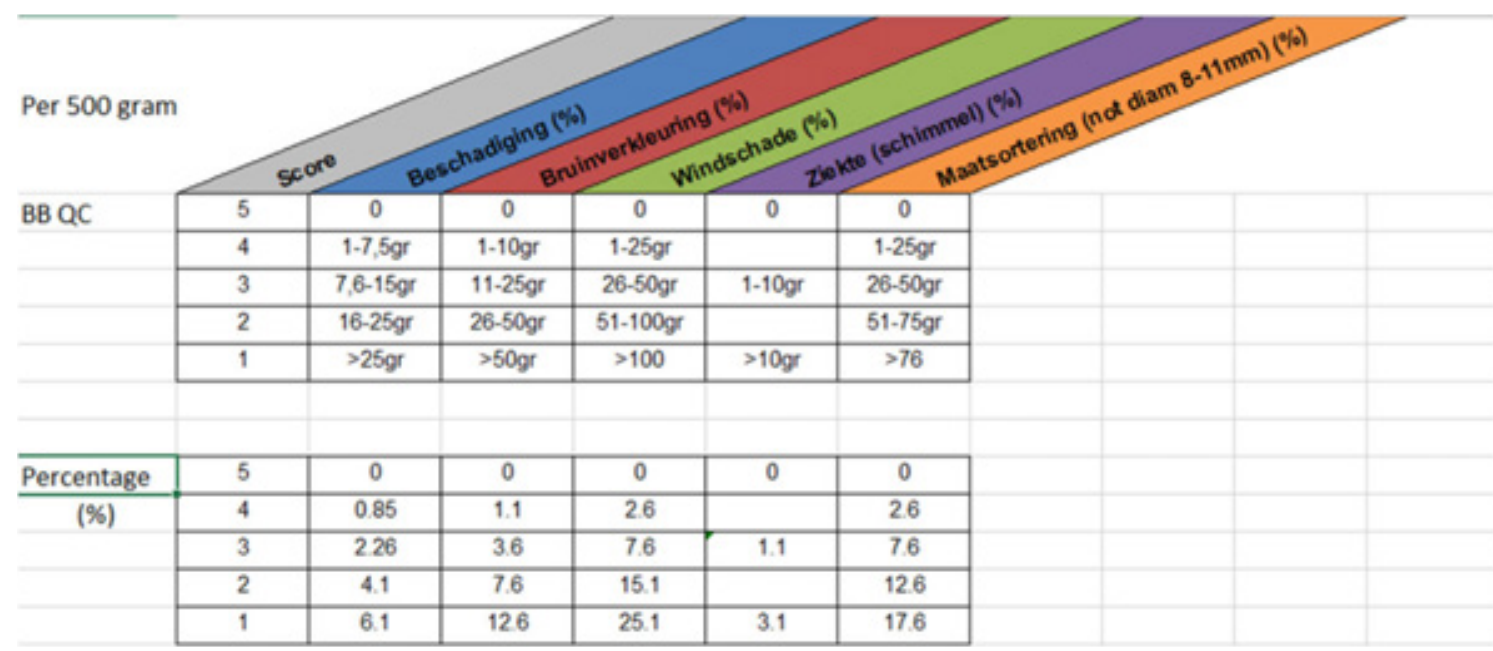

Figuur 1. Conversie van de visuele kwaliteitscontrole met 5 klassen van Bakker Barendrecht naar percentage. De percentages zijn berekend door de gemiddelden van de klassegrenzen te delen door de batchgrootte $(500 \mathrm{~g})$ en vervolgens om te zetten naar percentage.

\subsection{Vergelijking kwaliteit}

Door Bakker Barendrecht zijn er van juni tot en met december 2017 in totaal 94 monsters beoordeeld (Figuren 2, 3 en 4). In deze monsters waren beschadiging, bruinverkleuring en maatafwijkingen vrijwel altijd aanwezig, en dan meestal tot $3 \%$. Windschade kwam in een aantal periodes voor, en was soms wat hoger ( $8 \%$ en $25 \%$ ). Wanneer bonen niet aan de maat voldeden, dan was dit meestal $4 \%$, met uitschieters van 8 of $13 \%$. In een beperkt aantal gevallen werd ziekte (schimmel en/of rot) geconstateerd. Opvallend is dat hierbij ook scores 4 werden toegekend, terwijl de schaal voor ziekte geen mogelijkheid tot het scoren van een "4" bevat (zie bijlage 1 ). In de conversie naar percentages zijn deze scores gegroepeerd bij score 5 en dus omgerekend naar $0 \%$. De score voor kleurhomogeniteit van de monsters was over het algemeen hoog (data niet weergegeven).

Door Vezet zijn er in dezelfde periode 158 monsters beoordeeld (Figuren 2, 3 en 4). In deze monsters was in de periode juli tot en met oktober vaak meer dan $5 \%$ van de bonen beschadigd.

Bruinverkleuring kwam wisselend voor met soms uitschieters van meer dan $10 \%$ van de bonen. Windschade was de voornaamste schade en kwam in een groot aantal monsters in meer dan $20 \%$ van de bonen voor en soms in meer dan 50\%. In vrijwel alle monsters werden er bonen dunner dan $8 \mathrm{~mm}$ gevonden. In deze gevallen was meestal meer dan $10 \%$ van de bonen te dun. Slapheid werd regelmatig gevonden en dan meestal tot $10 \%$ van de bonen, met een enkele uitzondering boven $10 \%$. Ziekte werd niet geconstateerd. De score voor kleurhomogeniteit van de monsters was over het algemeen hoog (data niet weergegeven).

Door de grote schommelingen in de verschillende soorten schade gedurende het gehele jaar, kan er op basis van dit enkele jaar geen conclusie worden getrokken over afhankelijkheid van seizoen/maand. 
Een interessante waarneming is het lagere percentage schade bij de monsters die door Bakker Barendrecht zijn beoordeeld in vergelijking met de monsters die door Vezet zijn beoordeeld. Op het eerste gezicht zouden schades als beschadiging, bruinverkleuring, en slapheid veroorzaakt kunnen zijn door handelingen, transport en opslag tussen de beoordelingsmomenten. Echter, windschade zou hier niet door moeten worden beïnvloed, terwijl ook deze toch fors toe lijkt te nemen. Dit doet vermoeden dat het verschil in beoordelingsmethode bijdraagt aan de verschillen. Waar Bakker Barendrecht de monsters beoordeelde door deze te bekijken en er een score van 1-5 aan te geven, beoordeelde Vezet de monsters boon voor boon om vervolgens de gewichten van de verschillende schadevormen te noteren.

Een andere interessante waarneming is dat de aanwezigheid van ziekte bij Bakker Barendrecht verder in de keten (bij Vezet) niet meer naar voren kwam. Dit suggereert dat het percentage ziekte niet homogeen verdeeld was in de populatie of dat er tussen de twee kwaliteitscontroles een selectie heeft plaatsgevonden. Echter, aangezien de percentages schade door ziekte bij Bakker Barendrecht en Vezet zeer laag (tussen 0 en $1 \%$ ) zijn, blijven dit slechts suggesties en geen harde conclusies. 

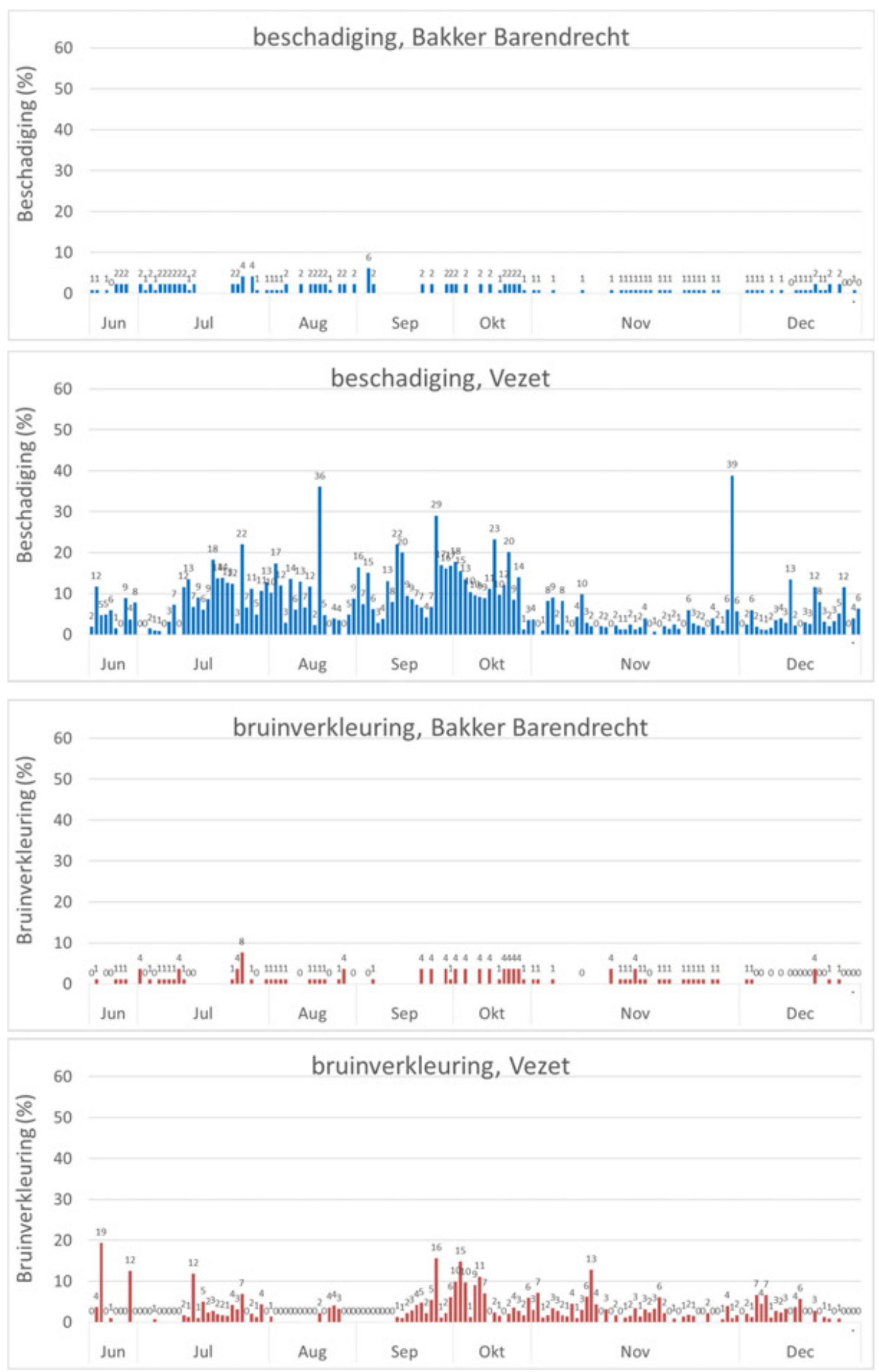

Figuur 2. Visueel beoordeelde beschadiging (bovenste grafieken) en bruinverkleuring (onderste grafieken) door Bakker Barendrecht en verderop in de keten door Vezet. Er is beoordeeld in de periode juni-december 2017 aan 94 monsters (Bakker Barendrecht) en 158 monsters (Vezet). 

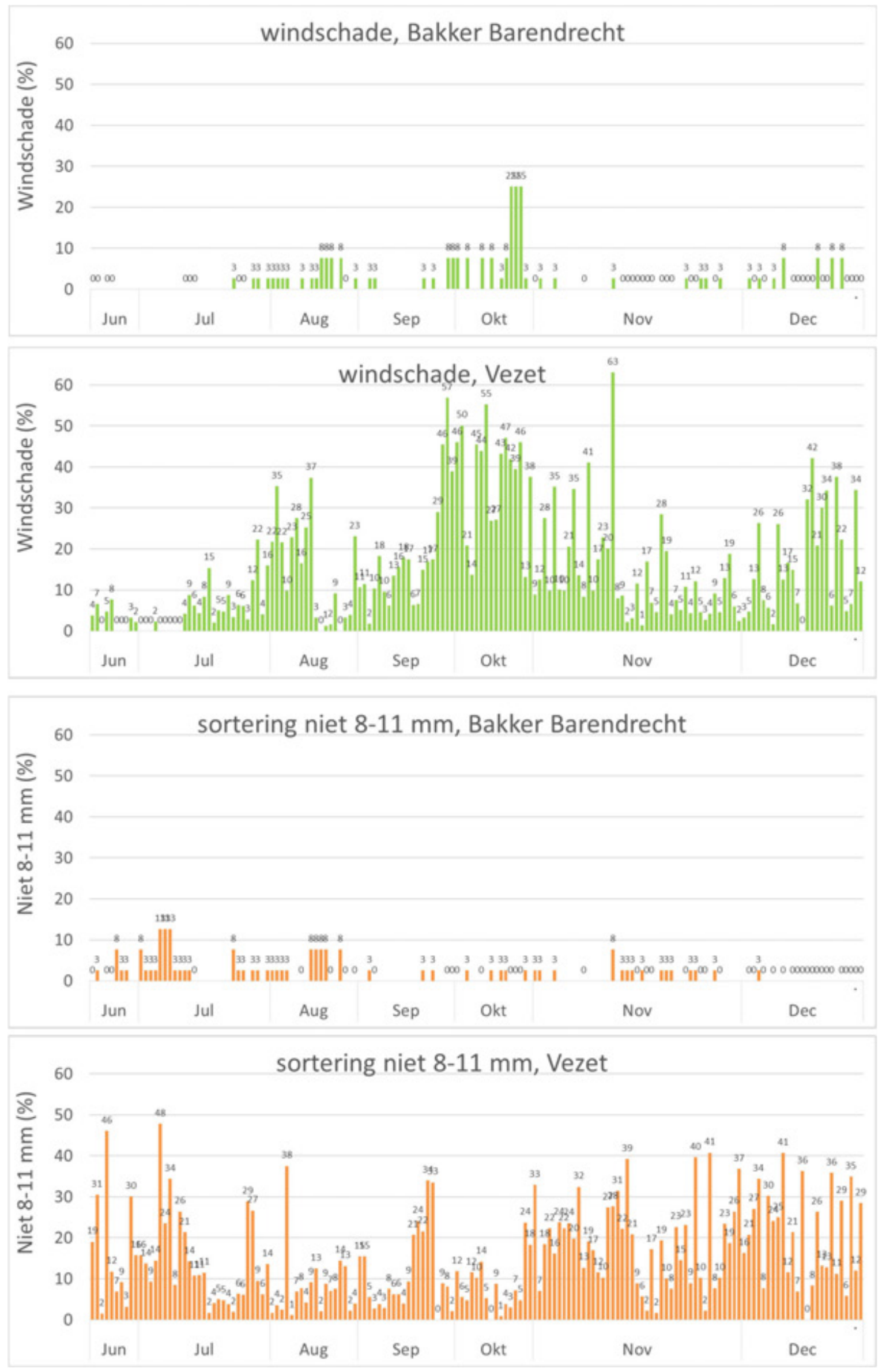

Figuur 3. Visueel beoordeelde windschade (bovenste grafieken) en afwijkende sortering (onderste grafieken) door Bakker Barendrecht en verderop in de keten door Vezet. Er is beoordeeld in de periode juni-december 2017 aan 94 monsters (Bakker Barendrecht) en 158 monsters (Vezet). 

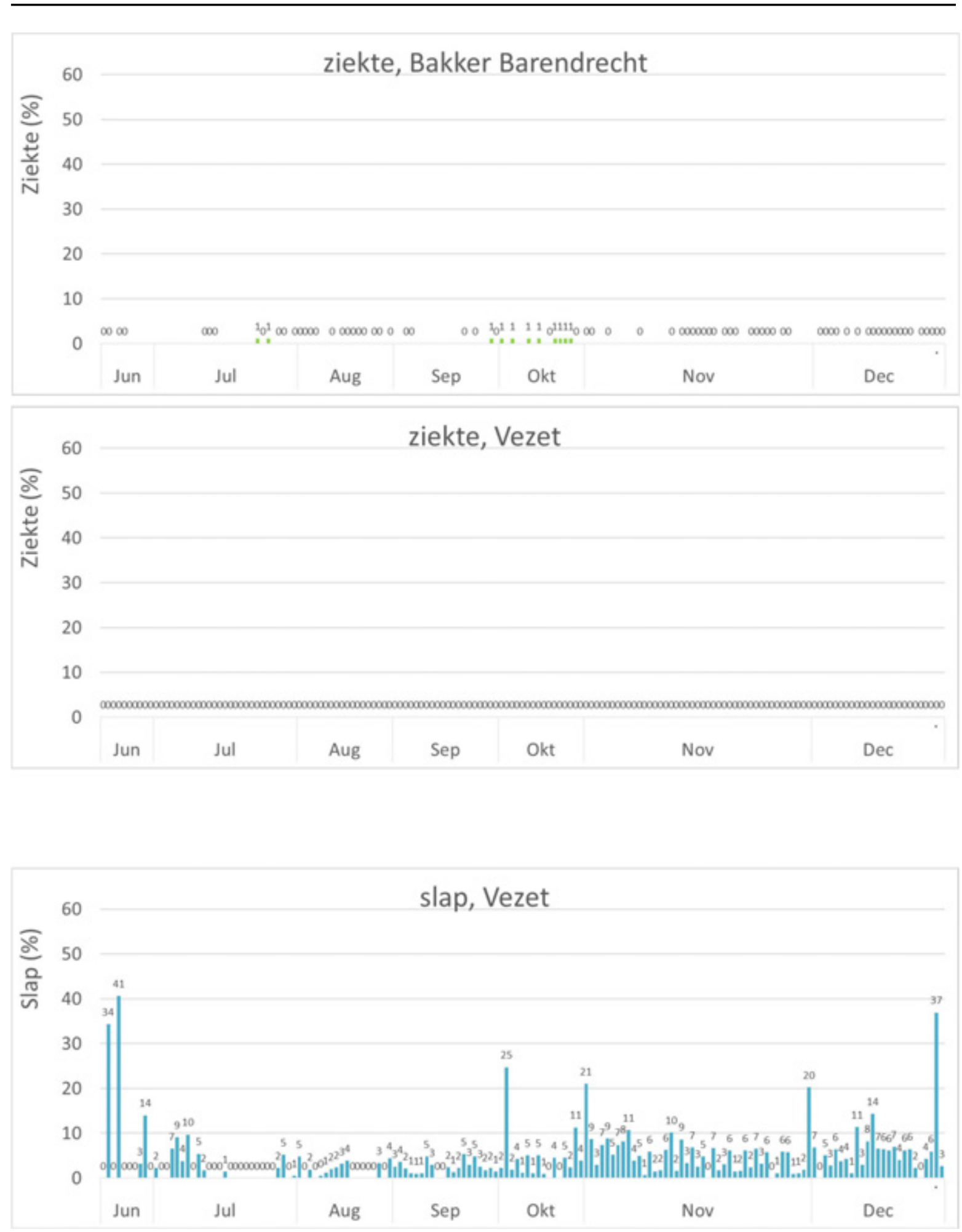

Figuur 4. Visueel beoordeelde ziekte (bovenste grafieken) en slap (onderste grafiek) door Bakker Barendrecht en verderop in de keten door Vezet. Slap is niet beoordeeld bij Bakker Barendrecht. Er is beoordeeld in de periode juni-december 2017 aan 94 monsters (Bakker Barendrecht) en 158 monsters (Vezet). 
Om te kijken of de kwaliteitscontroles van Bakker Barendrecht en Vezet vergelijkbaar zijn voor de verschillende schadesoorten is een multivariaatanalyse uitgevoerd. Uit deze analyse blijkt dat de correlatiecoëfficiënten van de kwaliteitscontroles niet sterk overeen komen (Tabel 1). De

correlatiecoëfficiënt voor kleurhomogeniteit was 0 , waarschijnlijk doordat vrijwel alle monsters een maximale score kregen bij Vezet. Bij beschadiging, bruinverkleuring en windschade waren de correlatiecoëfficiënten iets hoger, maar niet voldoende om te spreken van een geloofwaardig verband. Maatafwijkingen (not 8-11 mm) laten ook nauwelijks een verband zien, waarschijnlijk doordat deze hoog scoorde bij Vezet. Schimmel was niet aanwezig in de monsters bij Vezet, vandaar dat er geen correlatiecoëfficiënten te berekenen waren. Als toelichting op deze analyse is als voorbeeld de vergelijking tussen de twee bedrijven grafisch weergegeven voor het visueel beoordeelde kenmerk 'beschadiging' (Figuur 4).

Tabel 1 Correlatiecoëfficiënten van kwaliteitsmetingen van monsters uit pallets bonen genomen en beoordeeld bij Bakker Barendrecht en Vezet.

\begin{tabular}{|c|c|c|c|c|c|c|}
\hline \multirow[b]{2}{*}{$\mathrm{R}^{2}$} & \multicolumn{6}{|c|}{ Bakker Barendrecht } \\
\hline & $\begin{array}{l}\bar{d} \\
\overline{0} \\
\underline{\omega} \\
\bar{\vdots} \\
\frac{\omega}{\underline{\underline{\omega}}}\end{array}$ & 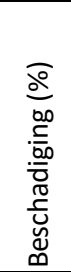 & 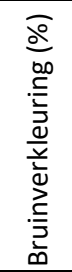 & 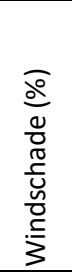 & 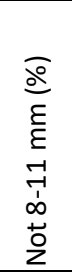 & 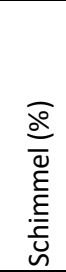 \\
\hline Vezet & 0.00 & 0.14 & 0.09 & 0.18 & 0.02 & $\mathrm{NaN}$ \\
\hline
\end{tabular}

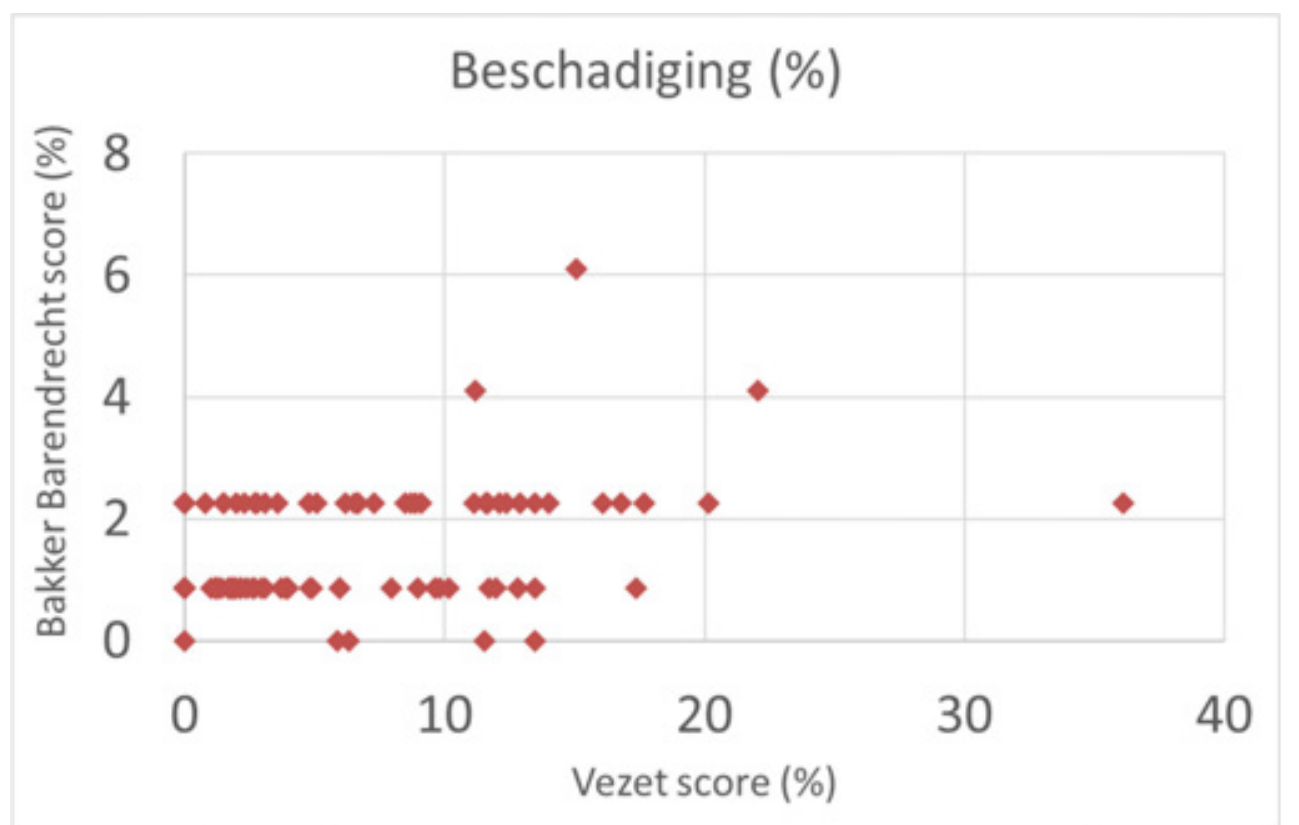

Figuur 4. Vergelijking van de visuele beoordeling van 'beschadiging' aan dezelfde monsters tussen Bakker Barendrecht (y-as) en Vezet (x-as).

Deze data laten zien dat de monstername in combinatie met de metingen niet goed met elkaar te vergelijken zijn tussen Bakker Barendrecht en Vezet. De vraag die hierbij kan worden gesteld is of dit komt door de verschillen in beoordelingsmethode (schatten versus wegen) of door de ontwikkeling van schade door opslag en transport tussen de kwaliteitsbeoordelingen van de twee bedrijven.

In het geval dat de schades zich ontwikkelen tijdens opslag en/of transport tussen de twee bedrijven, zou aangenomen kunnen worden dat de schade toeneemt met de duur hiervan. Correlatie van de tijd tussen de kwaliteitscontroles met de verschillen in deze controles suggereert echter dat de toename in schade zoals gemeten tussen Bakker Barendrecht en Vezet niet samenhangt met de totale tijd tussen de kwaliteitsmetingen (Tabel 2). Hiernaast is ook gekeken of de kwaliteit zoals gemeten door Vezet samen zou hangen met de tijdsduur tussen de metingen (Tabel 3). Ook hier waren de correlatiecoëfficiënten te laag om een verband te kunnen leggen tussen schade en tijdsduur vanaf ontvangst bij Bakker Barendrecht.

Echter, bij deze laatste twee vergelijkingen moet wel rekening gehouden worden met het feit dat de totale tijdsduur afhangt van verschillende stappen verdeeld over de bedrijven (opslag bij Bakker Barendrecht, transport, en opslag bij Vezet) en dus dat eventuele schadetoename zich misschien zou kunnen verhouden tot de duur van slechts één of meer van deze stappen. 
Tabel 2 Correlatiecoëfficiënten van de verschillen in kwaliteit van sperziebonen gemeten bij Bakker Barendrecht en Vezet (\ Bakker Barendrecht en Vezet) en het verschil in tijd tussen de kwaliteitsmetingen ( $\triangle$ Tijd QCs).

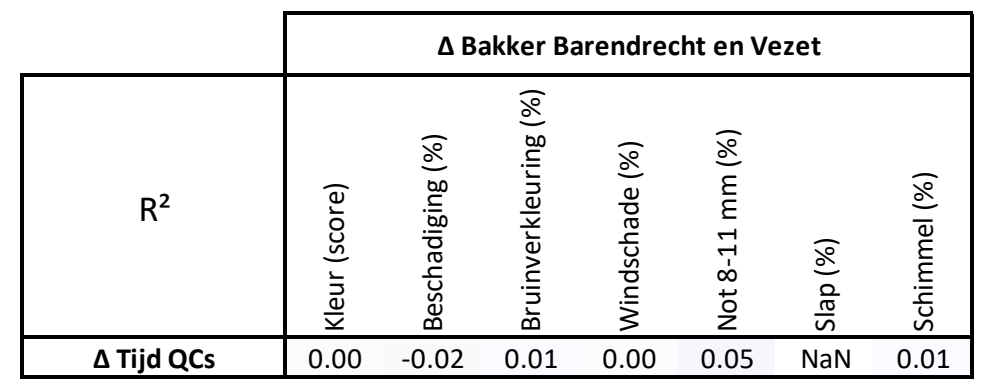

Tabel 3 Correlatiecoëfficiënten van de verschillen in kwaliteit van sperziebonen gemeten bij Vezet en het verschil in tijd tussen de kwaliteitsmetingen (D Tijd QCs).

\begin{tabular}{|c|c|c|c|c|c|c|c|}
\hline & \multicolumn{7}{|c|}{ Vezet } \\
\hline $\mathrm{R}^{2}$ & 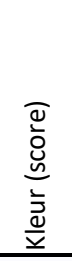 & 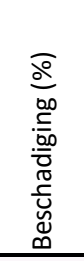 & 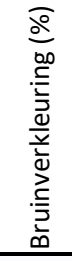 & 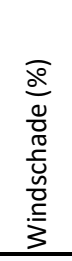 & 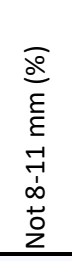 & $\begin{array}{l}\bar{a} \\
\frac{0}{\pi} \\
\frac{0}{n}\end{array}$ & 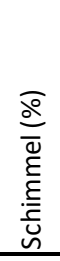 \\
\hline$\Delta \mathrm{Tijd}$ QCs & 0.00 & -0.03 & 0.00 & 0.00 & 0.03 & 0.04 & $\mathrm{NaN}$ \\
\hline
\end{tabular}

Naast een eventuele ontwikkeling van schade tijdens transport, kan het ook zijn dat verschillen in beoordelingsmethode bijdragen aan het waargenomen verschil in kwaliteit. Hierbij dient zowel te worden gekeken naar de monstername als naar de beoordeling zelf. Bij monstername zijn selectiekeuzes belangrijk, zoals waar op de pallet en in het krat de monsters worden genomen of uit worden samengesteld en of er, bewust of onbewust, een voorselectie plaatsvindt. Bij de beoordeling zelf is belangrijk tot in welke mate het monster door wordt geplozen en hoe de hoeveelheid schade uiteindelijk wordt bepaald. Hierbij kunnen verschillende keurmeesters een meetmethode anders interpreteren en kan dit ook nog eens variëren per dag.

Voor zover er in deze analyse is gezien, lijkt de methode van schadebepaling door Vezet kritischer doordat iedere boon afzonderlijk wordt beoordeeld en de totale schade wordt gewogen. Echter, om te kunnen concluderen of de methodes vergelijkbaar zijn, zouden ze op dezelfde monsters, op dezelfde dag en onder hetzelfde licht moeten worden beoordeeld. 


\section{$4 \quad$ Conclusies en aanbevelingen}

Dit onderzoek leidt tot de volgende conclusies en aanbevelingen:

- De resultaten van de kwaliteitscontrole van Bakker Barendrecht en Vezet zijn moeilijk te vergelijken. Een mogelijke oorzaak is een verschil in bemonstering en/of meetmethode. Een andere oorzaak kan zijn dat schade zich heeft ontwikkeld in het traject tussen de twee bedrijven.

- Om een verschil in bemonstering- en/of meetmethode te voorkomen is het advies om de kwaliteitscontrole bij beide bedrijven op elkaar af te stemmen. Dit door gezamenlijk één beoordelingsmethode toe te passen of verder te ontwikkelen.

- Ook kan er schadeontwikkeling plaats gevonden hebben in de keten tussen de twee bedrijven. Uit de resultaten blijkt echter, dat de tijdsduur vanaf ontvangst bij Bakker Barendrecht tot aan beoordeling bij Vezet geen verband lijkt te houden met het niveau van de gemeten schade.

- $\quad$ Voor conclusies met betrekking tot periode afhankelijke schade (seizoen, maand) zijn meerdere jaren van dataverzameling nodig, liefst gekoppeld aan teelt-data.

- Voor een éénduidige klassenindeling bij de kwaliteitscontrole uitgevoerd door Bakker Barendrecht is het advies om bij de volgende beschadigingen; "sortering score 4", "windschade score 4" en "ziekte score 3" de klassenindeling vanaf " 1 gram" in plaats van "0 gram" te starten.

\section{Dankwoord}

De auteurs bedanken Bakker Barendrecht en Koninklijke Vezet BV voor het uitvoeren en het verstrekken van de kwaliteitsbeoordelingen en de uitstekende samenwerking in dit deelproject van GreenCHAINge Groenten \& Fruit. Tevens willen de auteurs Topsector Tuinbouw \& Uitgangsmaterialen bedanken voor het financieren van het project. 


\section{Bijlage 1 Beoordeling sperziebonen (Bakker Barendrecht)}
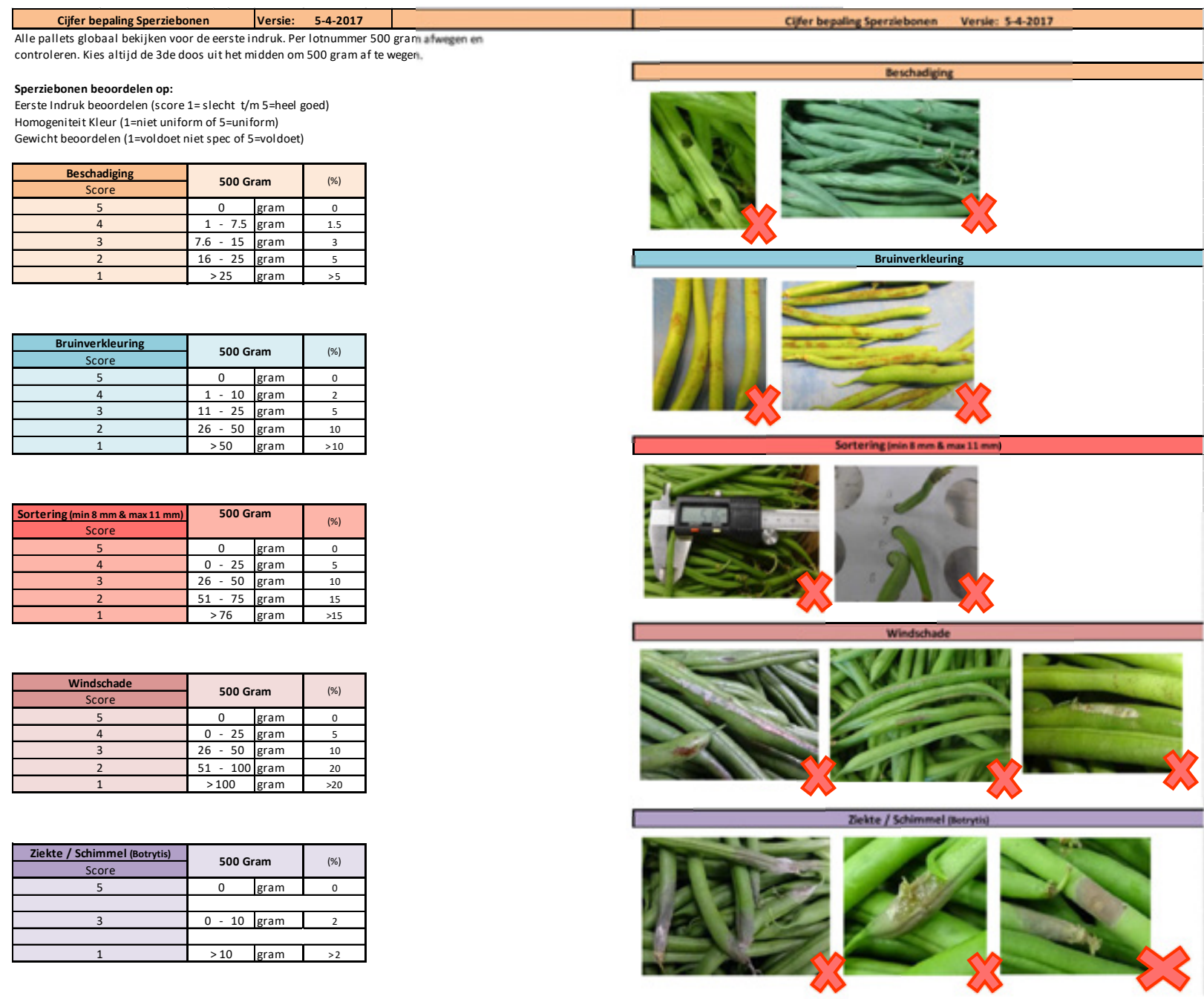


\section{Bijlage 2 Beoordeling sperziebonen (Vezet)}

Uitgangspunten

Monsters verse sperziebonen van ongeveer 500 gram worden beoordeeld.

\section{Beoordeling verse bonen}

- Beoordeel op de datum van levering, en vul de 'datum beoordeling' in.

- Is dit niet mogelijk vul dan 'datum levering' en 'datum beoordeling' in.

- Vul het GB nummer in (dit is het interne Vezet nummer), het palletnummer en het order nummer. Het palletnummer staat op een sticker die op 1 van de dozen is geplakt, neem de laatste 9 cijfers en haal het laatste cijfer eraf. Het palletnummer op de sticker in bijgaand voorbeeld is dus 50895204.

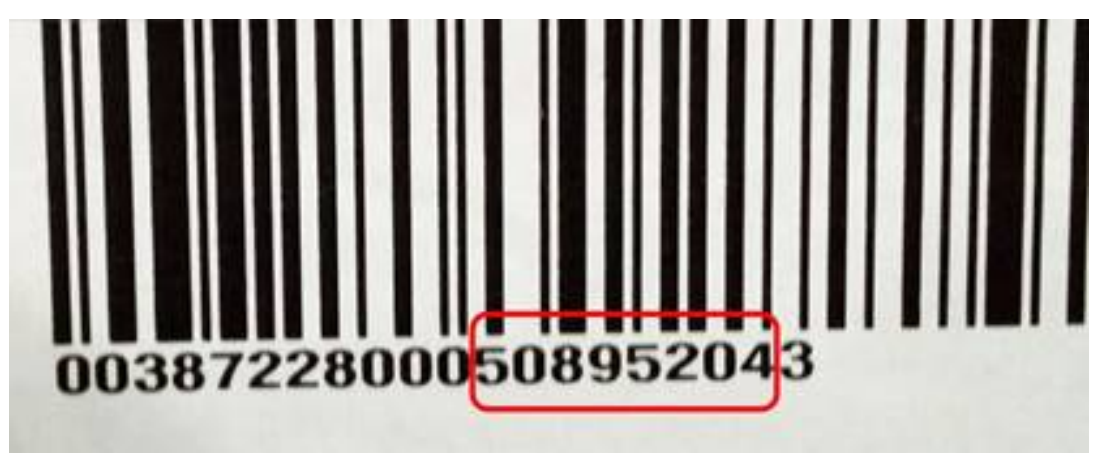

- Voor 'algemene indruk' en 'homogeniteit kleur' worden scores genoteerd, één score per monster.

- Voor de andere kwaliteit bepalende kenmerken worden de bonen per kenmerk gewogen.

- Bonen met verschillende kenmerken worden voor elk kenmerk apart gewogen, bijvoorbeeld: een slappe boon, met bruin verkleuring en een diameter van $7 \mathrm{~mm}$ wordt meegewogen met zowel 'grammen bruinverkleuring' als 'grammen slap' en 'grammen diam $<8 \mathrm{~mm}$ '.

- In het werkblad 'beoordeling verse bonen' is een kolom 'grammen intact' toegevoegd. Dit is om alle bonen met de juiste diameter $(8-11 \mathrm{~mm})$ en zonder gebreken te wegen.

- In grijze velden worden eigenschappen van de monsters ingevuld die te maken hebben met herkomst, datum aankomst, datum beoordeling en order, pallet en GB nummers.

- De witte velden zijn bedoeld om waarden in te vullen of opmerkingen te maken

- In de lichtblauwe velden verschijnen resultaten die berekend worden uit de ingevulde waarden.

- Vul alle waarden en opmerkingen behorende bij een monster in op één regel.

- Per monster één regel. 




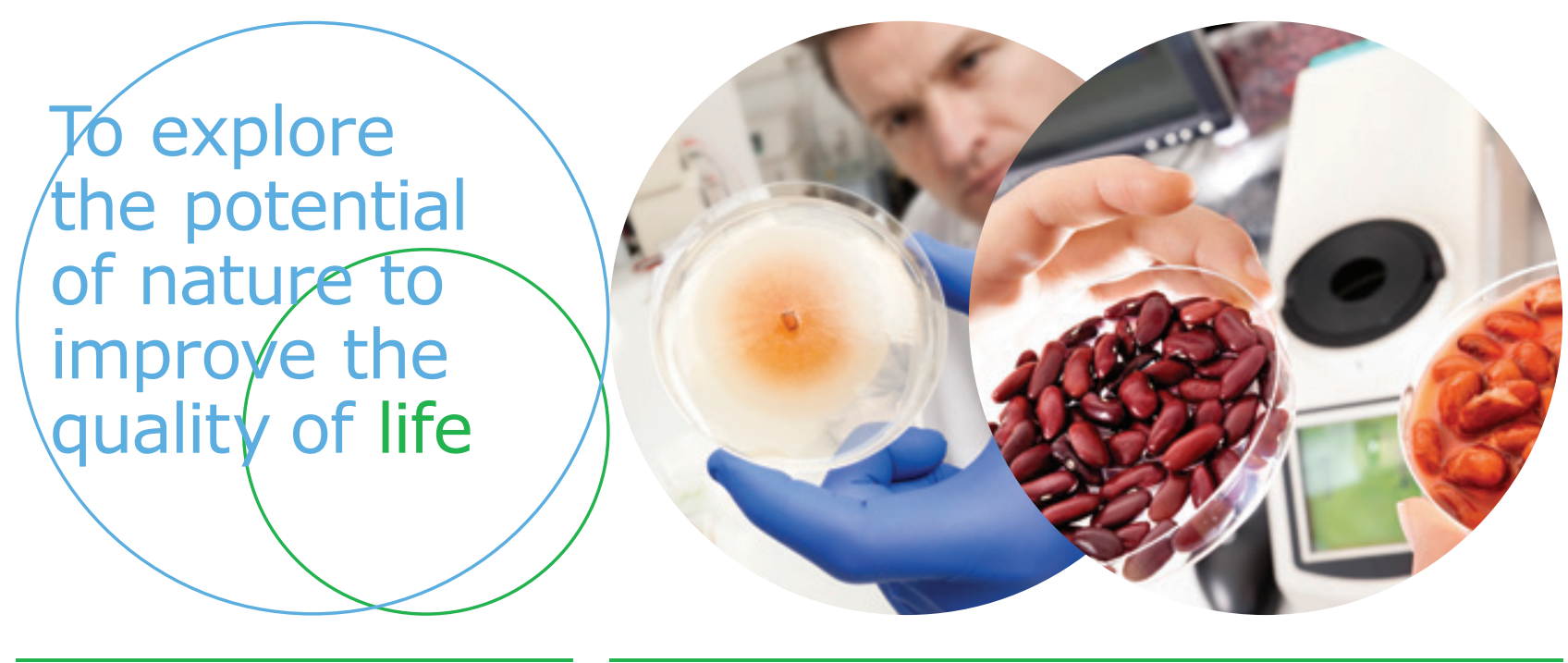

Wageningen Food \& Biobased Research Bornse Weilanden 9

6708 WG Wageningen

www.wur.nl/wfbr

info.wfbr@wur.nl

Rapport 1887
De missie van Wageningen University \& Research is 'To explore the potential of nature to improve the quality of life'. Binnen Wageningen University \& Research bundelen Wageningen University en gespecialiseerde onderzoeksinstituten van Stichting Wageningen Research hun krachten om bij te dragen aan de oplossing van belangrijke vragen in het domein van gezonde voeding en leefomgeving. Met ongeveer 30 vestigingen, 5.000 medewerkers en 10.000 studenten behoort Wageningen University \& Research wereldwijd tot de aansprekende kennisinstellingen binnen haar domein. De integrale benadering van de vraagstukken en de samenwerking tussen verschillende disciplines vormen het hart van de unieke Wageningen aanpak. 